\title{
HASIL AUTOPSI SEBAB KEMATIAN MENDADAK TAK TERDUGA DI BAGIAN FORENSIK BLU RSUP. PROF. DR. R. D. KANDOU MANADO TAHUN 2010-2012
}

\author{
Dione S. M. Bhaskara \\ Johannis F. Mallo \\ Djemi Tomuka
}

\begin{abstract}
Bagian Ilmu Forensik Fakultas Kedokteran Universitas Sam Ratulangi Manado
Email: dione.sophia@gmail.com
\end{abstract}

\begin{abstract}
According to WHO, sudden death is the death that occurred 24 hours after the symptom arise, but in some forensic cases, most of the death cases occurred in matter of minutes or might be seconds as the first symptom arise. Sudden deaths increase along the aging. Sudden deaths that caused by disease are often bring suspicion thus they need to be proven by doing the medicolegal autopsy, to which the result will be revealed. This research aims to determine the results of the autopsy cause of sudden unexpected death on forensic BLU department of RSUP. Prof. Dr. R. D. Kandou Manado in 20102012. This research is using retrospective descriptive method. Research population is all the alleged victims of sudden deaths in BLU. RSUP. Prof. Dr. R. D. Kandou Manado in 2010-2012. Sample is taken by total sampling method. There are 12 cases of sudden deaths, 4 of them are not qualified to be taken as sample because of incomplete data. The total of sudden deaths based on gender are 7 cases of Males $(87.5 \%)$, and 1 case of Female (12.5\%). Sudden death occurs more frequently in adult with 3 cases (37.5\%) on $41-59$ years old range. 3 cases on heart disease (37.5\%), 2 cases on lung disease (25\%), 1 case on lung cancer (12.5\%), and the other 2 are unknown reason (25\%). From this study, it is concluded that sudden deaths are more common to male in 41-59 years old range, and the most common cause of sudden death is cardiovascular system
\end{abstract}

Keywords: Sudden deaths, autopsy, cardiovascular system.

\begin{abstract}
Abstrak: Kematian mendadak menurut WHO adalah kematian yang terjadi pada 24 jam sejak gejalagejala timbul, namun pada kasus-kasus forensik, sebagian besar kematian terjadi dalam hitungan menit atau bahkan detik sejala gejala pertama timbul. Kejadian kematian mendadak meningkat seiring dengan bertambahnya usia. Kematian mendadak yang disebabkan oleh penyakit, sering mendatangkan kecurigaan sehingga perlu dibuktikan dengan dilakukannya autopsi medikolegal, yang hasilnya dapat menunjukkan sebab kematian tersebut. Penelitian ini bertujuan untuk mengetahui hasil autopsi sebab kematian mendadak tak terduga di Bagian Ilmu Kedokteran Forensik BLU. RSUP. Prof. Dr. R. D. Kandou Manado tahun 2010-2012. Penelitian ini merupakan penelitian deskriptif retrospektif. Populasi penelitian adalah seluruh korban dugaan mati mendadak di BLU. RSUP. Prof. Dr. R. D. Kandou Manado tahun 2010-2012. Pengambilan sampel menggunakan teknik total sampling. Terdapat sebanyak 12 kasus kematian mendadak, 4 diantaranya tidak memenuhi syarat untuk dijadikan sampel karena datanya yang tidak lengkap. Jumlah kematian mendadak berdasarkan jenis kelamin yaitu laki-laki sebanyak 7 kasus (87.5\%) dan perempuan 1 kasus (12.5\%). Kematian mendadak lebih banyak terjadi pada kelompok dewasa yaitu dengan usia 41-59 tahun sebanyak 3 kasus (37.5\%). Kematian mendadak akibat penyakit
\end{abstract}


jantung sebanyak 3 kasus (37.5\%), penyakit paru sebanyak 2 kasus (25\%), penyakit lainnya (tidak diketahui sebabnya) 2 kasus (25\%), dan kanker paru hanya terdapat 1 kasus (12.5\%). Dari penelitian ini disimpulkan bahwa kematian mendadak terjadi lebih sering pada laki-laki, serta paling banyak dialami pada usia 41-59 tahun. Penyebab tersering kematian mendadak diakibatkan oleh sistem kardiovaskular.

Kata Kunci: Kematian mendadak, autopsi, sistem kardiovaskular.

Definisi WHO untuk kematian mendadak adalah kematian yang terjadi pada 24 jam sejak gejala-gejala timbul, namun pada kasuskasus forensik, sebagian besar kematian terjadi dalam hitungan menit atau bahkan detik sejak gejala pertama timbul. Kematian mendadak tidak selalu tidak terduga, dan kematian yang tak diduga tidakselalu terjadi mendadak, namun amat sering keduanya ada bersamaan pada suatu kasus. ${ }^{1}$

Pengertian mati mendadak sebenarnya berasal dari sudden unexpected natural death yang didalamnya terkandung kriteria penyebab yaitu natural (alamiah, wajar). Mendadak disini diartikan sebagai kematian yang datangnya tidak terduga dan tidak diharapkan. ${ }^{2}$

Kematian mendadak yang disebabkan oleh penyakit, seringkali mendatangkan kecurigaan baik bagi penyidik maupun masyarakat umum; khususnya bila kematian tersebut menimpa orang yang cukup dikenal oleh masyarakat, kematian di rumah tahanan dan di tempat-tempat umum, seperti di hotel, cottage atau motel. ${ }^{3}$

Kecurigaan akan adanya unsur kriminal pada kasus kematian mendadak, terutama disebabkan masalah TKP nya, yaitu bukan di rumah korban atau di rumah sakit, melainkan di tempat umum. Dengan demikian kematian mendadak termasuk kasus forensik, walaupun hasil autopsi menunjukkan bahwa kematian korban karena penyakit jantung, perdarahan otak atau pecahnya aneurysma cerebri. ${ }^{3}$

Ilmu Kedokteran Forensik, juga dikenal dengan nama Legal Medicine, adalah salah satu cabang spesialistik dari Ilmu Kedokteran, yang mempelajari pemanfaatan ilmu kedokteran untuk kepentingan penegakan hukum serta keadilan. ${ }^{2}$
Dalam kasus forensik, penyebab kematian dapat di identifikasi dengan cara pemeriksaan medik dengan tujuan membantu penegakan hukum antara lain adalah pembuatan visum et repertum. Visum et repertum merupakan keterangan yang dibuat oleh dokter atas permintaan penyidik yang berwenang mengenai hasil pemeriksaan medik terhadap manusia, baik hidup atau mati ataupun bagian atau diduga bagian dari tubuh manusia, berdasarkan keilmuannya dan di bawah sumpah, untuk kepentingan peradilan. Visum et repertum adalah salah satu alat bukti yang sah sebagaimana tertulis dalam pasal 184 KUHAP. Visum et repertum menguraikan segala sesuatu tentang hasil pemeriksaan medik yang tertuang di dalam bagian pemberitaan, yang karenanya dapat dianggap sebagai pengganti benda bukti. ${ }^{2}$

Pemeriksaan medik lain yang sangat penting untuk mengidentifikasi penyebab kematian adalah autopsi. Autopsi berasal dari kata Auto $=$ sendiri dan Opsis $=$ melihat. Yang dimaksudkan dengan autopsi adalah pemeriksaan terhadap tubuh mayat, meliputi pemeriksaan terhadap bagian luar maupun bagian dalam dengan tujuan menemukan proses penyakit dan atau adanya cedera, melakukan interpretasi atas penemuanpenemuan tersebut, menerangkan penyebabnya serta mencari hubungan sebab akibat antara kelainan-kelainan yang ditemukan dengan penyebab kematian. Jika pada pemeriksaan ditemukan beberapa jenis kelainan bersama-sama, maka dilakukan penentuan kelainan mana yang merupakan penyebab kematian, serta apakah kelainan yang lain turut mempunyai andil dalam terjadinya kematian tersebut. ${ }^{4}$ 
Berdasarkan tujuannya, autopsi terbagi atas 3 yaitu autopsi klinik, autopsi forensik/medikolegal dan autopsi anatomi. ${ }^{5}$

Autopsi klinik dilakukan terhadap jenazah seorang yang diduga terjadi akibat suatu penyakit, tujuannya untuk menentukan penyebab kematian yang pasti, menganalisis kesesuaian antara diagnosis klinis dengan diagnosis post mortem, patogenesis penyakit dan sebagainya. Untuk autopsi ini diperlukan izin keluarga terdekat jenazah tersebut. ${ }^{5}$

Autopsi forensik/medikolegal dilakukan terhadap jenazah seseorang yang diduga meninggal akibat suatu sebab yang tidak wajar seperti pada kasus kecelakaan, pembunuhan maupun bunuh diri. Tujuan pemeriksaan ini adalah membantu penentuan identitas jenazah, menentukan sebab pasti kematian, mekanisme kematian dan saat kematian, mengumpulkan dan memeriksa benda bukti untuk penentuan identitas benda penyebab dan pelaku kejahatan, membuat laporan tertulis yang objektif berdasarkan fakta dalam bentuk visum et repertum. Autopsi forensik harus dilakukan sedini mungkin, lengkap, oleh dokter sendiri dan seteliti mungkin. ${ }^{5}$

Autopsi anatomi. Autopsi anatomi dilakukan terhadap mayat korban meninggal akibat penyakit, oleh mahasiswa kedokteran dalam rangka belajar mengenai anatomi manusia. Untuk autopsi ini diperlukan izin dari korban (sebelum meninggal) atau keluarganya. Dalam keadaan darurat, jika dalam $2 \times 24$ jam seorang jenazah tidak ada keluarganya maka tubuhnya dapat dimanfaatkan untuk autopsi anatomi. ${ }^{5}$

Menurut sistem tubuh, lesi yang menyebabkan kematian mendadak dapat dibagi atas: penyakit jantung dan pembuluh darah (penyumbatan arteri koroner, trombosis koroner, hipertensi, stenosis aorta, penyakit miokard, aneurisma sifilis), penyakit sistem respirasi (epiglottis), penyakit pada otak dan lesi intrakranial lain (ruptur aneurisma berry, perdarahan serebral, meningitis), penyakit sistem gastrointestinal, penyakit sistem urogenital, lain-lain (asthma dan epilepsi). ${ }^{6}$

Tujuan penelitian ini yaitu, untuk mengetahui dan memahami tentang autopsi, untuk mengetahui fungsi dan peranan autopsi pada kematian mendadak tak terduga dan untuk mengetahui penyebab kematian mendadak tak terduga.

\section{METODE PENELITIAN}

Penelitian ini menggunakan metode total sampling. Penelitian ini dimaksud untuk memberikan gambaran suatu penyakit/gejala tertentu yang didasarkan pada catatan medis dengan waktu peristiwanya terjadi di masa lalu. Dalam hal ini catatan medis yang diambil adalah catatan medis hasil autopsi kematian mendadak tak terduga di Bagian Ilmu Forensik BLU RSUP Prof. Dr. R. D. Kandou Manado periode tahun 2010-2012.

Pengambilan data diambil dan digunakan untuk sampel yaitu keseluruhan kasus kematian mendadak di Bagian Ilmu Forensik BLU RSUP Prof. Dr. R. D. Kandou Manado periode tahun 2010-2012 dengan kriteria inklusi yaitu dengan data yang lengkap dan kriteria eksklusi yang merupakan data yang kurang lengkap.

Definisi operasional yang digunakan yaitu: kematian mendadak (definisi WHO untuk kematian mendadak adalah kematian yang terjadi pada 24 jam sejak gejala-gejala timbul). ${ }^{1,3}$ Jenis kelamin yaitu laki-laki dan perempuan, usia dengan kategori 0-23 thn, 212 thn, 13-20 thn, 21-40 thn, 41-59 thn, $\geq 60$ thn, serta sebab kematian: penyakit jantung, kanker paru, penyakit paru dan jantung, penyakit lainnya.

\section{HASIL PENELITIAN DAN BAHASAN}

Dari hasil autopsi kematian mendadak tak terduga berdasarkan data yang diambil dari bagian forensik di RSUP. Prof. Dr. R. D. 
Kandou Manado tahun 2010-2012, diperoleh jumlah data 12 kasus kematian mendadak. Beberapa kasus diantaranya dikeluarkan dari penelitian ini karena terdapat 4 kasus yang tidak lengkap data hasil autopsinya.

Dalam penelitian ini tersisa, 8 kasus yang terdiri dari 4 dikarenakan penyakit jantung, 1 dikarenakan kanker paru, 1 dikarenakan penyakit paru dan jantung, 2 lainnya dikarenakan penyakit tetapi tidak dispesifikasikan jenis penyakitnya.

Distribusi korban kematian mendadak berdasarkan jenis kelamin

Distribusi frekuensi penderita menurut jenis kelamin dapat dilihat pada Gambar 1.

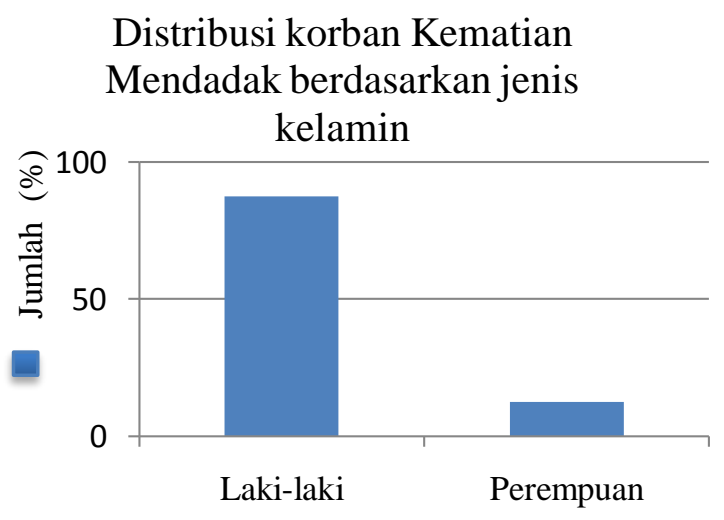

Gambar 1. Distribusi korban kematian mendadak berdasarkan jenis kelamin

Gambar 1 menunjukkan sebagian besar yang mengalami kematian mendadak adalah laki-laki yaitu sebanyak 7 orang $(87,5 \%)$, sedangkan perempuan yang mengalami kematian mendadak hanya 1 orang (12,5\%).

Hasil penelitian diatas jika dibandingkan dengan jumlah kematian mendadak yang diperiksa di bagian kedokteran forensik FKUI. Dalam tahun 1990, dari seluruh 2461 kasus, ditemukan 227 laki-laki (9,2\%) dan 50 perempuan (2\%) kasus kematian mendadak sedangkan pada tahun 1991 dari 2557 kasus, diperiksa 228 laki-laki (8,9\%) dan 54 perempuan $(2,1 \%)^{2}$
Dari penelitian ini disimpulkan bahwa kematian mendadak terjadi lebih sering pada laki-laki.

\section{Distribusi korban kematian mendadak berdasarkan usia}

Berikut ini distribusi penderita berdasarkan usia.

Distribusi korban kematian mendadak berdasarkan usia

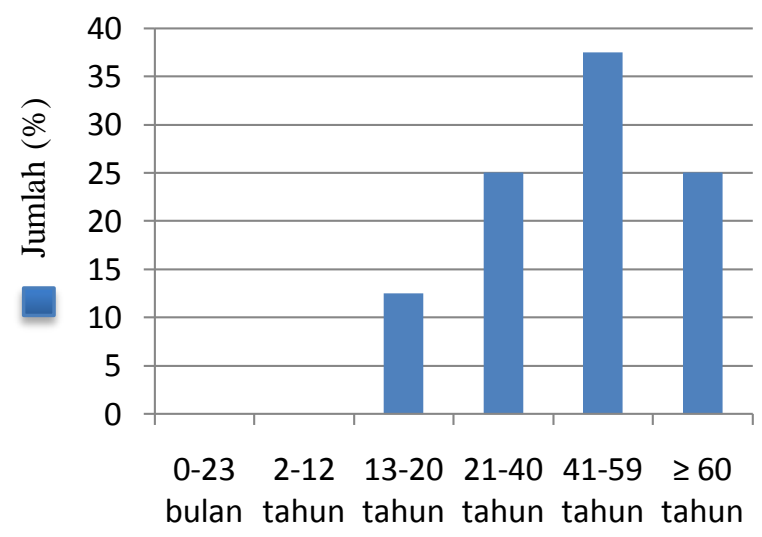

Gambar 2. Distribusi korban kematian mendadak berdasarkan usia

Hasil penelitian menunjukkan bahwa dari 8 orang yang mengalami kematian mendadak. Usia terbanyak adalah antara 41-59 tahun sebanyak 3 orang (37,5\%). Sedangkan kelompok usia 21-40 tahun dan $\geq 60$ tahun sama yaitu terdapat 2 orang (25\%), dan yang paling sedikit ditemui pada kelompok usia 1320 tahun hanya terdapat 1 orang (12,5\%). Dan pada usia 0-23 bulan dan 1-12 tahun tidak terdapat kasus yang mengalami kematian mendadak.

Dari hasil penelitian diatas, jika dibandingkan dengan hasil penelitian di RSUP Dr. Wahidin Sudirohusodo dan RSUD Labuang Baji Makassar menunjukkan, berdasarkan kelompok usia, penderita PJK sebagian besar adalah yang berumur 50-59 tahun dan umur $\geq 70$ tahun (46,7\%), 
sedangkan yang tidak menderita PJK sebagian besar berumur $<40$ tahun $(78,6 \%){ }^{7}$

Dari penelitian ini disimpulkan bahwa kematian mendadak paling banyak dialami pada usia 40-59 tahun. Hal ini dapat disimpulkan prevalensi usia berpengaruh terhadap orang yang mengalami kematian mendadak. ${ }^{7}$

\section{Distribusi korban kematian mendadak berdasarkan penyebab}

Berikut ini distribusi korban kematian mendadak mendadak berdasarkan penyebab.

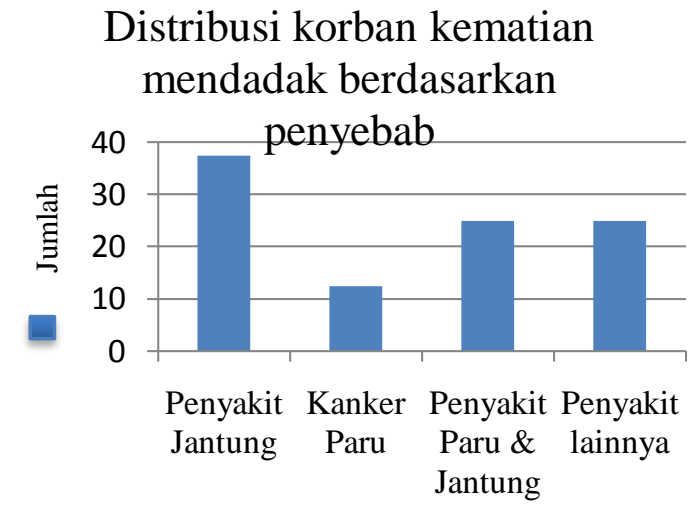

Gambar 3. Distribusi korban kematian mendadak berdasarkan penyebab

Dari hasil penelitian ditemukan bahwa dari 8 korban kematian mendadak, didapatkan korban terbanyak dengan penyebab penyakit jantung yaitu sebanyak 3 orang (37,5\%). Penyebab lainnya seperti penyakit paru dan jantung terdapat sebanyak 2 orang (25\%). Sedangkan untuk penyebab penyakit yang tidak diketahui sebabnya terdapat sebanyak 2 orang (25\%). Dan yang paling sedikit penyebabnya adalah kanker paru yaitu sebanyak 1 orang (12,5\%).

Menurut hasil penelitian kasus kematian mendadak yang penyebabnya penyakit pembuluh darah koroner merupakan penyebab kematian terbanyak. Hal ini dikarenakan peran berbagai faktor yang diduga ikut berpengaruh dalam meningkatnya kasus kematian mendadak. Salah satunya adalah pertumbuhan ekonomi yang menyebabkan perubahan pola konsumsi masyarakat, yaitu kebiasaan mengkonsumsi makanan cepat saji yang berprotein tinggi dan berlemak, tanpa diiringi dengan konsumsi makanan berserat. Perubahan tersebut berdampak dengan terjadinya peningkatan penyakit pada pembuluh darah yaitu aterosklerosis. ${ }^{8}$

Penyakit jantung dan pembuluh darah secara umum menyerang laki-laki lebih sering dibanding perempuan dengan perbandingan 7:1 sebelum menopause, dan menjadi 1:1 setelah perempuan menopause. Di Indonesia, seperti yang dilaporkan Badan Litbang Departemen Kesehatan RI, persentase kematian akibat penyakit ini meningkat dari 5,9\% (1975) menjadi 9,1\% (1981), 16,0\% (1986) dan 19,0\% (1995). ${ }^{9}$

Pada tahun-tahun terakhir ini, penyebab kematian tersering pada kasus kematian mendadak ialah penyakit kardiovaskular, sedangkan pada beberapa dekade yang lalu dilaporkan bahwa penyebab kematian tersering ialah penyakit infeksi saluran pernapasan. $^{2}$

Sebagai perbandingan, dapat dilihat bahwa penyakit kardiovaskular ditemukan pada 61,6\% dari 17.653 kasus kematian mendadak yang diperiksa di Hamburg dari tahun 1936 hingga 1964. Sedangkan Helperm dan Radson melaporkan sebesar 44,9\% dari 2030 kasus, oleh Weyrich sebesar 42\% dari 2668 kasus dan Lauren sebesar 51\% dari 403 kasus. $^{2}$

Risiko kematian akibat gagal jantung berkisar antara 5-10\% per tahun pada kasus gagal jantung ringan, yang akan meningkat menjadi $30-40 \%$ pada gagal jantung berat. ${ }^{10}$

Dari semua kasus kematian mendadak, sekitar 45\% disebabkan oleh patologi pada sistem kardiovaskular, 20\% sistem respiratori, $15 \%$ sistem saraf pusat, $6 \%$ sistem 
pencernaan, 4\% sistem saluran kemih dan genital, dan $10 \%$ penyebab lainnya. ${ }^{8}$

\section{SIMPULAN}

Berdasarkan hasil penelitian yang dilakukan di bagian Forensik BLU RSUP Prof. Dr. R. D. Kandou Manado periode tahun 2010-2012, didapatkan data mengenai profil korban mati mendadak di bagian Forensik periode tahun 2012-2012 ialah korban yang mengalami kematian mendadak terbanyak merupakan penderita laki-laki (87,5\%), korban yang mengalami kematian mendadak terbanyak pada kelompok usia 41-59 tahun (37,5\%) dan penyebab korban mati mendadak tersering ialah penyakit jantung (37,5\%).

\section{DAFTAR PUSTAKA}

1. James JP, Jones R, Karch SB, Manlove J. Simpson's Forensic Medicine. $13^{\text {th }}$ edition. London: Hodder \& Stoughton Ltd. 2011. p. 54-64.

2. Budiyanto A, Widiatmaka W, Sudiono S, Mun'im TWA, Sidhi, Hertian S et al. Ilmu Kedokteran Forensik. Jakarta: Bagian Kedokteran Forensik Fakultas Kedokteran Universitas Indonesia; 1997.

3. Idries AM. Pedoman Ilmu Kedokteran Forensik. Edisi Pertama. Jakarta Barat: Binarupa Aksara; 1997. h. 210.

4. C’torus V. Teknik Autopsi. 17 Jul 2011. [dikutip 05 Sep 2013]. Diunduh dari:
http://www.scribd.com/doc/60173860/TEKNI K-AUTOPSI

5. Husnah M. Autopsi. 11 Nov 2013. [dikutip 05 Sep 2013]. Diunduh dari: http://www.scribd.com/doc/183193013/sgd-3autopsi-docx\#download

6. Kristanto E, Winardi T. Kematian Mendadak. 05 Sep 2010. [dikutip 12 Feb 2014]. Diunduh dari: http://www.scribd.com/doc/36945361/KEMA TIAN-MENDADAK

7. Hermansyah, Citrakesumasari, Aminuddin. Aktifitas fisik dan kesehatan mental terhadap kejadian penyakit jantung koroner pada pasien rawat jalan di RSUP. Dr. Wahidin sudirohusodo dan RSUD Labuang Baji Makassar. Feb 2012. [dikutip 06 Sep 2013]. Diunduh dari: http://journal.unhas.ac.id/index.php/mgmi/arti cle/download/424/366

8. Singh S. Kematian Mendadak. Medan: Kedokteran Forensik FK USU. 2013. [dikutip 12 Feb 2014]. Available at: http://repository.usu.ac.id/bitstream/12345678 9/38686/5/Chapter\%20I.pdf

9. Rahmawati MLA. Hubungan antara usia dengan prevalensi dugaan mati mendadak. [skripsi] . Surakarta: Fakultas Kedokteran Universitas Sebelas Maret. 2010. [dikutip 12 Feb 2014]. Available at: http://eprints.uns.ac.id/139/1/1669203092010 09341.pdf

10. Ardiansyah M. Medikal Bedah Untuk Mahasiswa. Edisi Pertama. Jogjakarta: DIVA Press (Anggota IKAPI). 2012. h. 11. 